\title{
SPATIAL INTERACTIONS IN LOCAL POLICY MAKING: APPLICABILITY OF TAX COMPETITION AND TAX MIMICKING CONCEPTS TO LOCAL GOVERNMENT POLICIES ON TAX RATES AND USER CHARGES FOR SERVICES IN POLAND
}

DOI: https://doi.org/10.18509/AGB.2017.07

UDC:351.71/.72:336.225(438)

\author{
Paweł Swianiewicz ${ }^{1}$ \\ ${ }^{1}$ University of Warsaw, Department of Local Development and Policy, \\ Faculty of Geography and Regional Studies, Poland \\ Corresponding author: pswian@uw.edu.pl
}

Submitted: January 2017, Accepted: April 2017, Published: August 2017

\begin{abstract}
The main research question is how spatial proximity of other agents (neighboring municipalities) influences decision making of local politicians deciding upon user charges for local public services and rates of local taxes. The paper refers to concepts of tax competition and tax mimicking but it extends its usefulness beyond local taxes only, asking also about its applicability for decisions concerning fees for services such as water provision, fares for local public transport, or parking fees.

There are two types of competition discussed in the paper: classic competition for mobile tax base and yardstick competition, in which local politicians compete for political capital being related to comparison of tax rates with neighboring municipalities. The latter meaning is more applicable to user charges for services. The paper discusses theoretical concepts but also tests its applicability empirically through the multi-variate regression models. It suggests that due to relative importance for consumers, tax mimicking effect might be more visible in user charges than in policies regarding rates of local taxes.

The paper is based on results of the "Fees for local public services - financial and political importance" research project. The project is funded by Narodowe Centrum Nauki (National Science Centre) grant number UMO-2015/19/B/HS4/02898.
\end{abstract}

Key words: tax competition, local government, spatial interactions, user charges;

\section{Introduction}

For political geographer interested in local decision making and public finance the question of spatial interactions is the most interesting dimension in analysis of local financial policies. In this paper we try to apply the tax competition theory to understand the spatial interactions behind the variations in local government tax policies and policies concerning setting tariffs for local public services. The aim of the study is to examine how useful that concept might be to explain the behaviour of Polish municipal governments.

Although empirical study concentrates on Poland, it may have a wider importance for the whole region of Central and Eastern Europe. The concept has been recently applied in Polish local government studies to analyse tax policies [11], but now it is proposed to borrow the concept of competition to study tariffs of local services, such as charges for water provision and parking fees.

\section{The concept of tax competition - theoretical discussion}

The model of tax competition has been created to explain national tax policies, but it may be applied to the local level as well. Tax 
competition is defined in this paper as the situation in which the local tax rate in the given jurisdiction is changed as a reaction to the tax rates applied by neighbouring jurisdictions.

There are two different potential motives for tax competition:

- Competition for a mobile tax base, in which local government tries to attract movement of capital, companies or residents to the given jurisdiction. It leads to the growth of the local tax base, and in the ideal scenario, also to a resultant growth of budget revenues. The positive impact on the local budget can be direct (increased revenues from the tax of which the rate is a subject of competition) or indirect: e.g. local jurisdiction attracts new tax-payers through the competitive rate of the property tax, which indirectly generates new income from other taxes.

- Maintenance or increase of the political capital - tax rates are adjusted in the considered jurisdiction, taking into account the tax rates of the neighbouring municipalities in order to satisfy local voters and to secure political support in local elections. In this case one may talk not about 'classic' competition for the tax base, but about the concept known in economics as 'yardstick competition'.

In the latter case of 'yardstick competition' there is no reason to expect that reduction of the tax rate may be compensated for by the growth of the local tax base. In this case one may talk rather about the exchange between financial and political capital [7].

Blöchliger [1], in his interpretation of the reaction of tax-payers to tax rates, refers to Hirshman's concept of exit and voice strategies. The exit strategy may be identified with the first of two motives discussed above, since it assumes 'voting with the feet' and the moving of the tax base to another jurisdiction by 'members' who are not satisfied with the benefits of their membership of the club. The voice strategy (complaining, protesting) may be identified rather with 'yardstick competition' in which tax-payers argue for lower tax rates referring to the rates in neighbouring jurisdictions. In that case 'members' try to improve their position by expressing discontent and demanding changes in tax policy. Blöchliger suggests that a tax-payer has three potential reactions to the tax rate he/she is not satisfied with: moving to another jurisdiction (exit), reducing effort (e.g. not making an effort to earn extra income), and trying to avoid taxation (tax dodging).

The debate on the value of local tax competition has been prolonged and has never led to a unanimous conclusion. Antagonists issue a warning of the danger of a 'race to the bottom' and the underprovision of public services [8] as well as stress that the dynamics of tax competition between subnational governments is such that a local authority will not improve its relative position within the country and none will gain any long-lasting competitive advantages. The protagonists' arguments are rooted in their belief in the value of competition as such, which helps to achieve innovations and obliges elected politicians to strive for allocative efficiency [5].

What are the conditions which may increase or decrease the intensity of tax competition among local governments?

- Local tax autonomy - the more autonomy local governments have, the more likely is tax competition. It is important at the same time that the consequences of tax competition cannot be externalised. In particular, revenues from local governments' own taxes must not be substituted through financial transfers from higher government.

- Structure of local taxes - probability of tax competition is higher if local taxes have a mobile tax base.

- Territorial organization - tax competition is more likely in territorially fragmented systems, which minimize barriers to the migration of residents and of capital. Territorial fragmentation also makes it easier to compare tax rates in neighbouring jurisdictions,

- It is more likely to occur in smaller jurisdictions, in which economy is more open and they are more dependent on external investors.

Building on the asymmetry of information between voters (tax-payers) and political representatives Reulier \& Rocaboy [9] expect also that the decision on the local tax rate will depend on the variation of rates among neighbouring jurisdictions. The 
larger the variation is, the easier it is for politicians to apply higher tax rates in their own jurisdiction, since it is more difficult for voters to treat the surrounding region as a yardstick in the political debate. .

European empirical studies suggest that tax competition on a local level really exists and can be identified in several cases. A comprehensive review of identified cases of local tax competitions is provided by Blöchliger [1], [2]. The dominant opinion suggests that local tax competition in European countries is very limited. There are at least two reasons explaining that opinion. Firstly, the tax yields and the discretion of local governments are limited in Europe. Secondly, central policies mitigate tax competition through the rigid system of norms related to local services (which demand a fixed level of local spending) as well as through vertical and horizontal equalization systems.

Relatively numerous empirical studies of local tax competition in Western Europe have so far had practically no equivalents in Poland and very little reflection in other countries of the Central and Eastern Europe. One of a few exceptions is a work which trace local tax mimicking in the Czech Republic in the decisions on the property tax [10].

\section{Spatial interactions in local policies through tax competition in Poland - hypothesis for empirical tests}

The main research question is:

- Do changes of tax rates and of tariffs for local services in neighbouring municipalities induce similar changes in an analysed local jurisdiction?

In Poland potential space for local tax competition is limited to the municipal (gmina) tier only. Neither of two upper tier sub-national governments - county (powiat) nor regional (województwo) - have any discretion to decide upon rates of any taxes. And even on a municipal level the tax autonomy is limited. The tax levels are capped by the 'ceiling rates' imposed by the Parliament, so the decision of local government on tax rates is limited to the levying of the maximum possible or lower rates. Local governments may also grant tax reliefs or exemptions. The tax yields collected from local taxes provide a relatively modest part of local government revenues - on average it is about $20 \%$ of the total local budget revenues.

The most important local taxes, which are considered in our research include:

- Property tax from physical persons, which in practice means housing properties of local inhabitants;

- Property tax from legal entities, i.e. business (commercial) properties;

- Tax on agriculture, paid by farmers and depending on farm size and quality of soil;

- Tax on vehicles, which is levied on busses and lorries only (but not on passenger cars, motorcycles, or tractors used for farming), i.e. it is paid by some types of businesses.

Property tax provides about three quarters of all the 'discretionary revenues' (or over $12 \%$ of the total budget revenues) of municipal governments. More than four fifths of its tax yields are collected from business properties, while residential properties are taxed with very low tax rates and provide less than one fifth of the revenues from the tax. Tax on vehicles (providing less than $1 \%$ of total municipal revenues) is interesting owing to its relatively mobile tax base. Therefore one can expect tax competition in relation to it, although, on the other hand, the low significance of this tax for total budget revenues and a very limited number of potential tax-payers may reduce the interest in policies related to the tax. Tax on agriculture is important in traditional rural local governments (although in the scale of whole country it provides just below $2 \%$ of municipal revenues). Moreover, in some rural areas it is the only tax paid by most of voters. For several rural tax-payers the tax on agriculture constitutes a more heavy tax burden than the tax on housing property.

In case of property tax from legal entities there is no tax mobility in the literal sense migration of a given property is impossible. But changing the location of business activity influenced by the local tax rates is likely to happen. Therefore, one may expect 
tax competition efforts by local governments, which would aim at positive spillover for the local budget through higher income tax revenues from employees of the re-located company.

In case of tax on agriculture and housing property tax the mobility of the tax base is very low or non-existent, although the classic 'voting with the feet' model referred originally to migration of residents. But in practice, such a migration is very unlikely to happen, especially in a situation where the property tax is very low (in Poland the maximum rate per square meter of the housing property is less than 0.25 euro).

If evidences for classic tax competition are to be found in Poland, it is expected that in case of tax on vehicles and commercial property tax the dominant motive would be the stimulation of local economic development. But in the case of the two other taxes the possible motive would be related to 'yardstick competition' and the desire to maintain political capital.

Similarly, most of policy decisions concerning tariffs for local services is made on a municipal level. In particular municipal governments can decide upon:

- Charges for water supply and for sewage produced by households. It is operator of the system (often company owned by local government) who proposes the new tariff. The calculation of the price is based on a formula prescribed by the Law. At a first glance the system looks very technocratic with no much space for policy making or inter-jurisdictional competition. But in practice it leaves a lot of space of manoeuvre for the mayor and the local council who makes a final decision;

- Fees for waste collection. Since 2014 the new regulation has transferred responsibility for setting the price system to local governments who organize a tender for operator of the system, which is financed by semi-tax paid by all residents to the municipal budget. The law prescribes only the maximum level of the fee, and defines various (alternative) ways of its calculating (it may be charger on per capita basis, per household, per square metre or proportionally to water consumption);

- Tickets for local public transport;

- Rents for communal housing.

The main hypothesis may be summarized in following items:

- local taxes constitute a minor part of budget revenues and they are also a small part of the tax burden imposed on citizens and businesses. It concerns especially taxes paid by households. In 2015 local taxes provided almost $20 \%$ of municipal revenues, but less than one third of the collected tax yield originated from physical persons, while over $70 \%$ was paid by business. In case of the main local tax - the property tax - the proportion was even lower, with businesses carrying burden of $85 \%$ of the total tax yield. Therefore tax policy may attract only limited interest from both sides (local politicians and taxpayers). We expect that tax competition among municipal jurisdictions does exist, but it is of relatively minor importance for the final outcome of tax policies. Moreover, we expect more yardstick competition aimed at maintenance of political capital than classic competition for a mobile tax base.

- We expect more intense yardstick competition in case of tariffs for local services, especially water and sewage, i.e. services which are provided by all municipalities and where comparison with tariffs applied in neighbouring jurisdictions is particularly easy.

In their theory of typical responses for fiscal stress, Wolman and Davis [12] suggest, that increasing charges for services is politically easier than raising rates of local taxes. That observation has been confirmed in some European studies - e.g. in Swiitzerland [6], in Norway [4] and Denmark [3]. Dafflon notes that tax competition in Switzerland has been leading to local tax rates reduction (phenomenon known as race to the bottom). In such a situation the increase of tariffs for local services may compensate the loss of tax yields. It is often accompanied by the 
effectiveness argument - reduction of subsidies to local services helps to liquidate illusion of free lunches and improves efficiency in allocation of resources. But part of explanation is that comparing of tariffs with neighbor communities is less often that in case of rates of local taxes. Therefore reduction of taxes helps politicians to present to their voters in "better light" even if they increase user charges at the same time. We suggest the opposite logic to be applied in Polish environment, and perhaps also in several other countries of Central and Eastern Europe, where local taxes play even more marginal role than in Poland. Since local taxes are limited, we expect more competition (similar to tax mimicking phenomenon) in tariffs for local services. In 2015 in Poland, residents paid about 6.6 billion Polish złoty ${ }^{1}$ in main local taxes (compared to over 16 billion paid by local companies). At the same time, the mount paid as tariffs for local services was much larger. The budget revenues from tariffs for water, sewage, waste collection and public transport were over 7.6 billion. But budget revenues from tariffs are only a small part of (much more difficult for a precise estimation) charges collected directly form users by entities responsible for provision of services (most often municipal companies or budgetary enterprises). Therefore, potential interest of voters in level of tariffs is higher than in the level of local taxes.

Methodologically, the issue of testing to what extent the rates in an analysed municipality are dependent in the level of rates in neighbouring local governments is complex. The level of tax rates (or tariffs) depends on several other characteristics of the local environment, such as population size, the wealth of the local community etc. In some cases these other explanatory variables are related to the features connected to the location of the local jurisdiction. In particular it concerns the distance from major agglomerations. In suburb municipalities taxes are often higher than elsewhere, because local governments may tax the location rent. As a consequence, even if there is a positive correlation

\footnotetext{
${ }^{1} 1$ euro = approx. 4.3 Polish złoty
}

between the tax level in analysed municipality and tax levels in neighbouring local governments, it is not certain sure if one may ascertain that relationship to be the outcome of the tax competition, or rather to 'common location' (e.g. in the vicinity of the large urban centre). That relationship is investigated through the Hierarchical Multiple Regression model, that allows to specify a fixed order of entry for variables in order to control for the effects of covariates and to test the effects of certain predictors independent of the influence of others. In the model correlation with tax rates of the neighbours will be controlled by the distance from agglomerations and other factors. The model which we test may be summarized in the following equation:

The empirical test of local tax rates has been conducted for 496 municipalities located in three different Polish regions. The same logic may be applied to analysis of spatial interactions of tariffs for local services.

$T R(i)=f(\overline{N T R}, \sigma(N T R), L E(i))+\varepsilon$

Where:

$T R(i)$ - tax rate or tariff in municipality $i$

$\overline{N T R},-$ mean of tax rates of tariffs in neighbouring municipalities $\left(\overline{N T R}=\frac{\sum_{j=1}^{n} T R(j)}{n}\right.$, where $n$-number of municipalities which are neighbours of municipality $i$ )

$\sigma(N T R)$ - standard deviation of tax rates or tariffs among neighbouring municipalities

$L E(i)$ - local environment measured by population size, wealth of local community and distance from large agglomeration centres

$\varepsilon$ - residual.

The empirical test of local tax rates has been conducted for 496 municipalities located in three different Polish regions. The same logic may be applied to analysis of spatial interactions of tariffs for local services.

\section{Results and discussion}

The tests of spatial interactions of tax policies have been conducted through the regression models. If similarity of tax rates in neighbouring municipalities is caused more by the similar conditions than by pure 'neighbouring factor', then the variation should be explained better by factors such as 
the affluence of the local community or the distance from large urban agglomerations. But if the impact of the neighbourhood remains significant after including the other controlling variables in the model, it may mean that tax competition plays a role in explaining the variation in tax policies. Dependent variables are rates of the local taxes, while the list of independent variables includes two which are related to potential tax competition (tax rate in neighbouring municipalities and standard deviation of tax rates in neighbouring municipalities) and three related to the broader context in which tax policies are adopted (population size, affluence of local community, and distance

Table 1: Regression models explaining rates of agriculture tax levied by municipalities in the three Polish regions (2012 data, $\mathrm{N}=496$ ).

\begin{tabular}{|c|c|c|}
\hline & $\mathrm{R}^{2}$ & Sign. \\
\hline & 0.570 & 0.000 \\
\hline & Beta & Sign. \\
\hline \multicolumn{3}{|l|}{ Affluence of local community } \\
\hline Population size & 0.127 & 0.000 \\
\hline \multicolumn{3}{|l|}{ Distance to agglomeration } \\
\hline Tax rate in neighbourhood & 0.728 & 0.000 \\
\hline SD in neighbourhood & & \\
\hline
\end{tabular}

Note: Beta coefficients are quoted only in the case of a relationship significant on 0.05 level.

Blank spaces mean no significant impact of the variable.

Source: own calculations on the basis of municipal budget reports.

How this picture fits with the variation in tariffs for locally provided services? The systematic analysis based on statistical methods is still ahead, but the illustration on figure 1 shows an anecdotic example of high pressure exerted by comparison with water and sewage charges in surrounding to the large urban agglomeration). The results of the test confirm that spatial interaction related to neighbourhood factor does matter (for more details see [11]), although the explanatory power of constructed models differs depending on the tax. The best predictions of the tax rates one gets in the case of agriculture tax (see table 1). The property tax is next, with rates for housing properties explained better than rates levied on commercial properties. But in general the average tax rate among neighbouring municipalities remains the most powerful explanatory factor in all the tested models. municipalities. This is a picture of poster prepared by bottom-up group of residents protesting against tariffs for sewage. The text says: "sewage system = robbery? We pay 11 złoty for cubic metre, our neighbours pay on average 4.55 złoty".

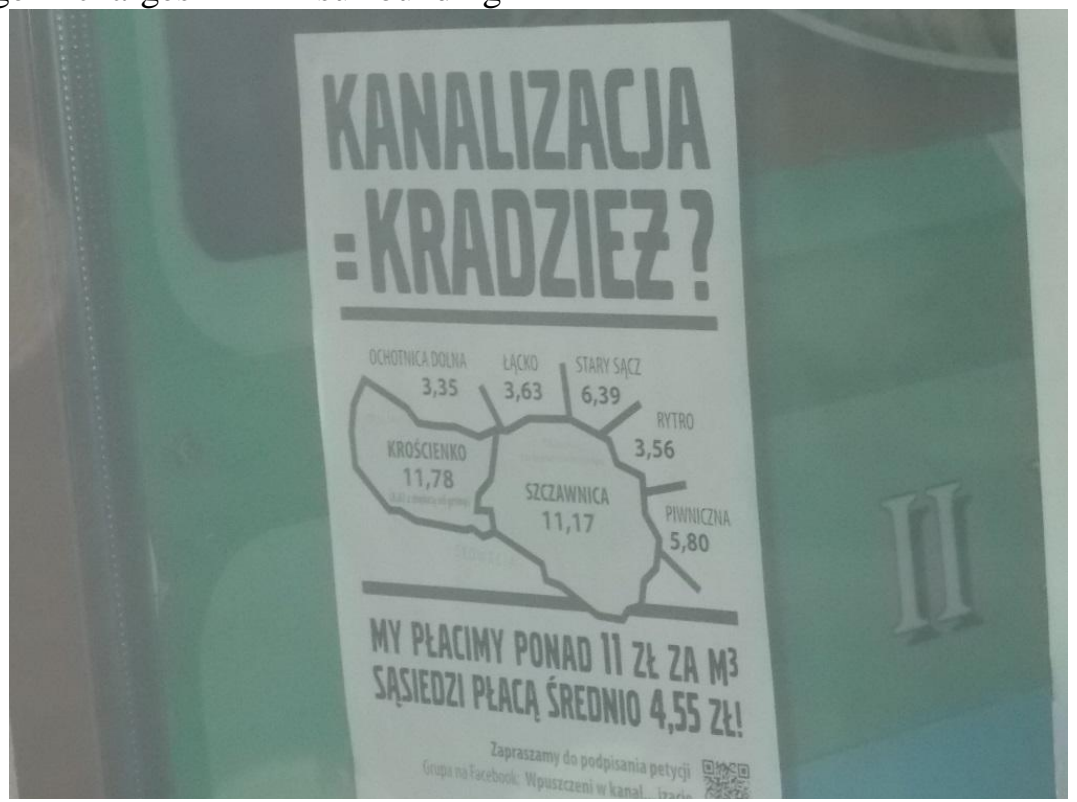

Figure 1. Poster on prices of sewage in Szczawnica municipality, Poland (December 2015) 
What is important from our point of view is a logic of argumentation behind the poster, fitting perfectly with the "yardstick tax competition" theory applied to tariffs for local services. There might be several factors beyond the variation of prices (e.g. natural environment which influence costs, population density, costs of recent investments etc.) but the campaign concentrates on simple spatial comparison and it has important political meaning.

Of course the single case is not sufficient test of the formulated hypothesis, but it confirms that the positive result of the test is likely to be found.

\section{References}

[1] Blöchliger, H. 'Fiscal federalism 2014: making decentralization work', Paris: OECD, 2013.

[2] Blöchliger, H \& Pinero-Campos, J 'Tax Competition Between Sub-Central Governments', OECD Working Papers on Fiscal Federalism, No. 13, OECD Publishing, 2011.

[3] Blom-Hansen, J., Bækgaard, M., Serritzlew, S. 'Tax Limitations and Revenue Shifting Strategies in Local Government', Public Budgeting and Finance, 2014, vol. 34(1): 64-84.

[4] Borge L.E. 'Charging for Public Services: the case of utilities in Norwegian local governments', Regional Science and Urban Economics, 2000, Vol. 30.

[5] Buchanan, J \& Musgrave R.A. 'Public finance and public choice: two contrasting visions of the state', The MIT Press, Cambridge, MA - London, 1999.

[6] Dafflon, B. 'Charging for local services: why and how? A critical assessment of Swiss practices in the last two decades', in: Junghun Kim, J. Lotz \& N.J. Mau (eds.) Interaction between local expenditure responsibilities and local tax policy, Rosendahls: Danish Ministry for Economic Affairs and the Interior and The Korea Institute of Public Finance, 2015.

[7] Mouritzen, P.E. 'What is a fiscal crisis?', in: PE Mouritzen (ed.) Managing cities in austerity: urban fiscal stress in ten western countries, Sage, London-Newbury Park-New Delhi, 1993.

[8] Oates, W. 'Fiscal Federalism', Harcourt, Brace and Jovanovic, New York, 1972.

[9] Reulier, E. \& Rocaboy, Y. 'Regional tax competition: evidence from French regions', Regional Studies, 2009, vol. 43(7): 915922.

[10] Sedmihradská, L. \& Bakoš, E., 'Municipal Tax Autonomy and Tax Mimicking in Czech Municipalities', Lex localis-Journal of Local Self-Government, 2016, vol. 14(1): 7592.

[11] Swianiewicz, P. \& Łukomska, J. 'Local tax competition in Poland?', Miscelanea Geographica, 2016, 20(3): 37-43

[12] Wolman, H. \& Davis, B. Local Government Strategies to Cope with Fiscal Stress, Washington: Urban Institute, 1980. 